\title{
Post-Crisis Fiscal Policy Priorities for the ASEAN-5
}

\author{
Nina Budina and Anita Tuladhar
}




\title{
IMF Working Paper
}

Asia and Pacific Department and Fiscal Affairs Department

Post-Crisis Fiscal Policy Priorities for the ASEAN-5

Prepared by Nina Budina and Anita Tuladhar ${ }^{1}$

Authorized for distribution by Paolo Mauro and Thomas R. Rumbaugh

November 2010

\begin{abstract}
This Working Paper should not be reported as representing the views of the IMF. The views expressed in this Working Paper are those of the author(s) and do not necessarily represent those of the IMF or IMF policy. Working Papers describe research in progress by the author(s) and are published to elicit comments and to further debate.

This paper focuses on post-crisis fiscal priorities in the ASEAN-5 economies-Indonesia, Malaysia, Philippines, Singapore and Thailand. Sound economic fundamentals and timely and forceful policy responses to the crisis, including fiscal stimulus, contributed to rapid economic recovery in the ASEAN-5. As growth rebounds, these economies are beginning to identify, communicate and implement their strategies for unwinding the fiscal stimulus while addressing long-term growth challenges. In this context, the paper highlights the need for fiscal policies to address infrastructure gaps, stimulate private consumption and expand social safety nets. Creating fiscal space to address these challenges will require raising revenues and reorienting public spending rather than increasing borrowing. Supporting structural reforms, aiming to stimulate private infrastructure investment, could help address long-term growth challenges, while easing the burden on fiscal policy.
\end{abstract}

JEL Classification Numbers: E62, H2, H5, H6, O53

Keywords: Fiscal policy, fiscal reforms, revenue measures, government expenditures, infrastructure

Author's E-Mail Address: nbudina@imf.org; atuladhar@imf.org

\footnotetext{
${ }^{1}$ The authors would like to thank Benedict Clements, David Coady, Paolo Mauro, and Mauricio Villafuerte for helpful comments and suggestions, Junhyung Park and John Piotrowski for excellent research assistance, and Katia Chen and Nong Jotikasthira for editorial assistance. All errors are our own.
} 


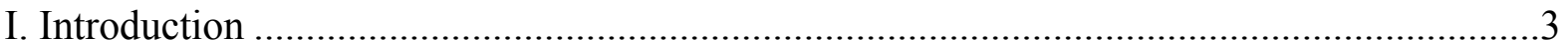

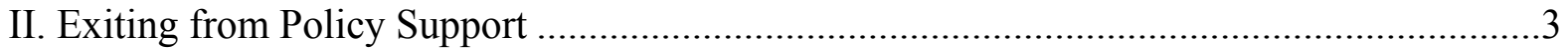

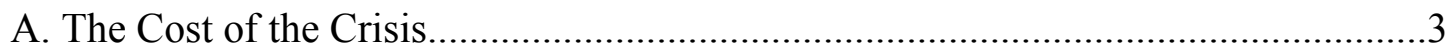

B. Post-Crisis Outlook ........................................................................................... 5

C. Exit from Fiscal Policy Support ............................................................... 8

III. The Role of Public Policy in Strengthening Future Growth Potential...............................9

A. Key Challenges: Addressing Infrastructure Gaps ............................................ 9

B. Key Challenges: Strengthening Private Consumption, Alleviating Poverty and Preparing for an Ageing Population ........................................................................ 12

IV. Fiscal Space to Foster Medium-Term Growth ............................................................. 15

A. Creating Fiscal Space by Re-Orienting Spending Priorities .................................16

B. Creating Fiscal Space through Revenue Reforms ............................................... 18

C. Frameworks for Maintaining Fiscal Credibility .................................................19

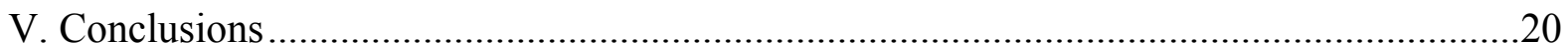

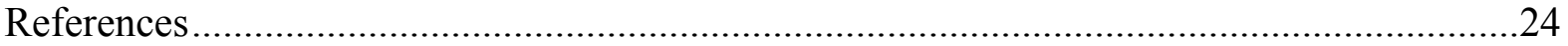

\section{TABLES}

1. General Government Overall Fiscal Balances ..................................................................4

2. Comparison of the 2009 Fiscal Positions Across the ASEAN-5 ......................................4

3. Comparison of the 2010 Fiscal Positions Across the ASEAN-5 ......................................6

4. General Government Debt and Primary Balance........................................................ 7

5. Ranking on Basic Infrastructure in the Asia-Pacific........................................................ 10

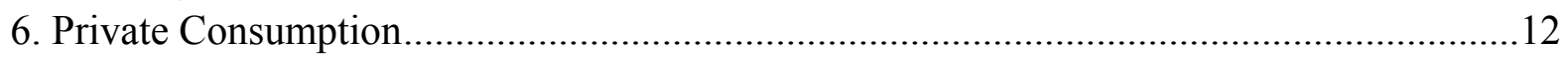

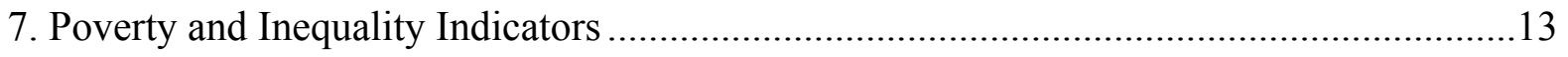

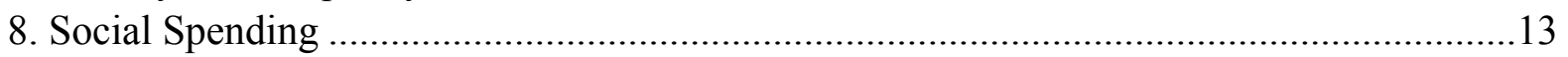

9. General Government Expenditure Structure: Selected Asian Economies, 2008 ...............17

10. Revenue Structure: Selected Asian Economies, 2008 ............................................. 19

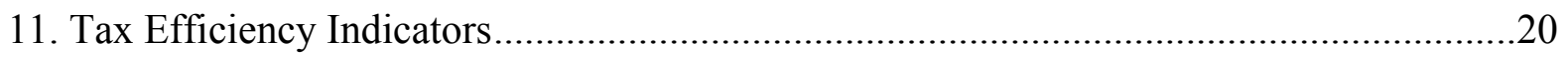

\section{FigURES}

1. Investment Commitments to Infrastructure Projects with Private Participation in

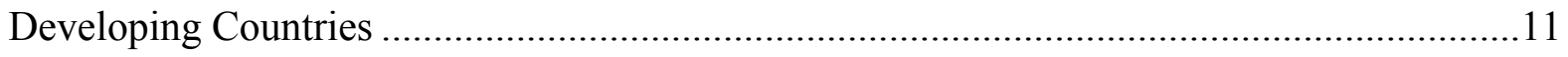

2. Gross Fixed Public Capital Formation.............................................................................11

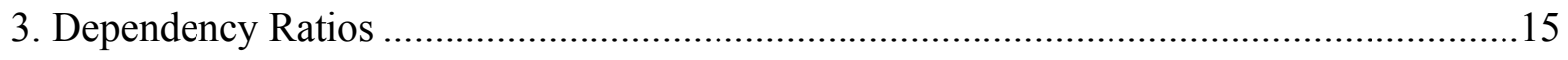

\section{AnNeX}

Quality of Basic and Technology Infrastructure. 


\section{INTRODUCTION}

Sound fundamentals and quick and forceful policy responses, including fiscal stimulus, contributed to economic recovery in the ASEAN-5 in the aftermath of the crisis. ${ }^{2}$ As these economies are recovering, the near-term challenge is to identify, communicate and begin to implement fiscal exit strategies from policy support. In addition, fiscal policies in the ASEAN-5 economies can help strengthen their future growth potential. This paper reviews the impact of the recent global financial crisis for fiscal policy and distills lessons for designing and implementing strategies for exit from fiscal policy support. The paper also discusses the role of fiscal policy in meeting infrastructure needs, stimulating private consumption and expanding social safety nets in most of the ASEAN-5 economies.

This paper draws on recent IMF staff analysis on the fiscal implications of these challenges and presents policy lessons that have particular relevance for the ASEAN-5. The paper is organized as follows: Section II reviews the impact of the crisis and highlights the near-term challenge of navigating the exit strategies in the ASEAN-5 economies. Section III discusses the role of public policy in strengthening future growth potential, focusing on the medium-term challenges of addressing infrastructure gaps, enhancing private consumption, and alleviating poverty. Section IV highlights options for creating and preserving fiscal space for additional public spending needed to help address the growth challenges.

Section V concludes.

\section{EXITING FROM POLICY SUPPORT}

\section{A. The Cost of the Crisis}

In response to the worst worldwide economic and financial crisis since the Great Depression, government budgets and central banks around the world have provided substantial support. Fiscal deficits widened significantly in 2009, with advanced economies experiencing a larger - and likely long lasting — deterioration (Table 1). With fiscal deficits above 9 percent of GDP in 2009, the scale of the problem in advanced G-20 countries is unprecedented. Emerging economies also experienced large deficits in 2009, but the impact of the crisis was on average less severe than in the advanced G-20 economies.

In the ASEAN-5, the fiscal impact of the crisis mirrored these developments, though the impact was somewhat less severe than in emerging G20 economies as a whole. Overall fiscal balances weakened by 3 percent of GDP on average, in 2009 relative to pre-crisis levels, well below the fiscal deterioration in advanced economies (Table 1).

\footnotetext{
${ }^{2}$ For the purposes of this paper, the ASEAN-5 consist of Indonesia, Malaysia, Philippines, Thailand, and Singapore.
} 
Relatively strong starting fiscal positions provided space for stimulus packages in the ASEAN-5. Even with recent fiscal expansions, fiscal positions remain relatively sound, having benefited from years of prudence. Better starting fiscal balances in Indonesia and especially, Singapore explain relatively better fiscal balances in 2009, despite the impact of the crisis (Table 2). However, there is a significant variation among the ASEAN-5 countries, with a large overall surplus in Singapore, near balance positions in Thailand and Indonesia, and deficits in Malaysia and the Philippines.

Table 1. General Government Overall Fiscal Balances (In percent of GDP)

\begin{tabular}{lcccccccc}
\hline & Average 05-07 & & & & & & \\
& Pre-crisis & 2008 & 2009 & 2010 & 2011 & 2012 & 2013 & 2014 \\
\hline ASEAN-5 & 0.3 & -0.2 & -2.8 & -2.2 & -1.7 & -1.6 & -1.8 & -1.7 \\
$\quad$ Indonesia & -0.1 & -0.1 & -1.6 & -1.5 & -1.7 & -1.6 & -1.6 & -1.6 \\
Malaysia & -2.6 & -3.2 & -5.5 & -4.6 & -5.5 & -5.2 & -5.0 & -4.8 \\
Philippines & -1.9 & -1.3 & -3.9 & -3.9 & -3.5 & -2.8 & -2.0 & -1.9 \\
Singapore & 6.4 & 5.1 & -0.9 & 2.4 & 1.5 & 1.8 & 1.9 & 2.1 \\
Thailand & 1.3 & 0.1 & -3.2 & -2.7 & -2.3 & -1.6 & -1.5 & -1.4 \\
Industrial Asia & -2.6 & -3.4 & -9.1 & -8.7 & -7.7 & -6.7 & -6.4 & -6.1 \\
$\quad$ Australia & 2.0 & -0.5 & -4.1 & -4.6 & -2.5 & -0.6 & 0.1 & 0.4 \\
Japan & -3.7 & -4.1 & -10.2 & -9.6 & -8.9 & -8.1 & -7.8 & -7.6 \\
New Zealand & 3.0 & 0.1 & -3.5 & -4.8 & -4.2 & -2.9 & -2.1 & -1.4 \\
Emerging and NIEs & -1.1 & -1.7 & -4.3 & -3.9 & -3.2 & -2.7 & -2.2 & -1.9 \\
Asia & -1.5 & -2.1 & -5.5 & -5.0 & -4.3 & -3.6 & -3.2 & -2.9 \\
Advanced G-20 & -2.2 & -4.3 & -9.5 & -8.7 & -7.4 & -5.4 & -4.7 & -4.5 \\
Emerging G-20 & 0.1 & -0.3 & -4.7 & -4.0 & -3.2 & -2.7 & -2.3 & -2.0 \\
\hline
\end{tabular}

Source: IMF, World Economic Outlook, October 2010.

Notes: Averages are weighted by GDP at purchasing power parity adjusted exchange rates. For Indonesia and the Philippines, figures are for the central government.

Table 2. Comparison of the 2009 Fiscal Positions Across the ASEAN-5 (In percent of GDP, unless otherwise indicated)

\begin{tabular}{lcrrrr}
\hline -/+ Deficit Increasing/Reducing Factors & Indonesia 2/ & Malaysia & Philippines 2/ Singapore 1/ & Thailand \\
\hline 2009 fiscal balance & -1.6 & -5.5 & -3.9 & -0.9 & -3.2 \\
2008 fiscal balance & -0.1 & -3.2 & -1.3 & 5.1 & 0.1 \\
Change in fiscal balance in 2009 (I - II) & -1.5 & -2.3 & -2.7 & -6.0 & -3.3 \\
$\quad$ Fiscal impulse (deterioration (-)/improvement(+)) & -1.4 & -1.1 & -2.3 & -4.9 & -1.3 \\
$\quad$ Automatic stabilisers & -0.2 & -1.2 & -0.5 & -1.1 & -2.1 \\
$\quad$ Additional (net) interest spending & 0.1 & 0.0 & 0.1 & 0.0 & 0.1 \\
Memorandum items: & & & & -1.3 \\
Real GDP growth (in percent) & 4.5 & -1.7 & 1.1 & -2.2 \\
Gross public debt to GDP ratio & 28.6 & 55.4 & 48.9 & 110.0 & 45.2 \\
\hline
\end{tabular}

Sources: IMF, World Economic Outlook, October 2010 and Fund staff estimates.

$1 /$ Net public sector debt is negative, as public sector assets are much larger than the gross public sector debt. Gross official reserves in 2009 are US $\$ 84$ billion (100 percent of GDP), in addition to US $\$ 100$ billion assets of the GIC Fund.

2/ For Indonesia and the Philippines, figures are for the central government. 
Much of the change in fiscal positions in the ASEAN-5 is explained by discretionary fiscal stimulus packages $^{3}$ (Table 2). In Indonesia, where growth declined but remained healthy, at 4.5 percent in 2009, the fiscal stimulus package was about half of the ASEAN-5 average for the year, reflecting the lower need for a countercyclical policy response. As a result, the 2009 deficit was much lower in Indonesia than in most of the ASEAN-5, except in Singapore.

In addition to stimulus packages, other underlying fiscal trends have played a role. For example, population aging and health care costs were already putting pressure on public finances and structural deficits in some ASEAN-5 economies (e.g., Singapore, see Figure 3, Section IV.A). Furthermore, fiscal deficits increased because of a long lasting, if not permanent, decline in revenues resulting from large contractions in international trade or the financial sector and associated asset/real estate price declines.

The operation of automatic stabilizers exacerbated the fiscal impact of the crisis in the ASEAN-5, though their impact was smaller than in advanced economies. In the ASEAN-5, the fiscal impact of automatic stabilizers was about 1 percent of GDP, lower than their impact in advanced economies (close to 2 percent in the advanced G-20), where governments are larger, and a greater share of spending is directly linked to the economic cycle. Within the ASEAN-5, automatic stabilizers have been relatively small in Indonesia and the Philippines and larger in Malaysia and Thailand, where the macroeconomic impact of the crisis was stronger. Finally, a slight reduction in interest payments despite larger borrowing requirements across the ASEAN-5 helped contain fiscal deficits in 2009.

\section{B. Post-Crisis Outlook}

The post-crisis fiscal and debt outlook is projected to deteriorate significantly in many countries around the world in 2010 and beyond. In advanced G-20 countries, fiscal deficits are projected well above their pre-crisis levels, leading to a sizable accumulation of public debt. The deterioration is expected to be more pronounced among advanced economies, as compared to emerging market economies. Underlying spending pressures - in particular, increased social security outlays and higher health and pension spending - are expected to further increase pressures on deficits. ${ }^{4}$

The fiscal outlook in the ASEAN-5 is much stronger than in the advanced economies. With the recovery of economic activity being more entrenched in Asia, including in the ASEAN-5,

\footnotetext{
${ }^{3}$ Fiscal stimulus packages in the ASEAN-5 were predominantly expenditure-based. Spending measures comprised 100 percent of the total package in Malaysia, 80 percent in Singapore and Philippines, and 70 percent in Thailand, compared to only 60 percent on average for the G-20 countries. Only in Indonesia was the fiscal stimulus package mostly revenue-based.

${ }^{4}$ These sections draw on IMF work on the fiscal challenges and post-crisis fiscal issues. For more details see Cottarelli and Viñals (2009), IMF (2010a), IMF (2010b), and Horton, Kumar, and Mauro (2009).
} 
many countries have already started a gradual exit from policy support in 2010, although in some cases, this may be postponed to 2011. This policy response reflects a stronger than anticipated economic rebound, but also the need to manage risks to public debt sustainability, especially in some countries experiencing aging-related spending pressures.

Table 3. Comparison of the 2010 Fiscal Positions Across the ASEAN-5

(In percent of GDP, unless otherwise indicated)

\begin{tabular}{|c|c|c|c|c|c|}
\hline -/+ Deficit Increasing/Reducing Factors & Indonesia 2/ & Malaysia & Philippines 2/ & Singapore $1 /$ & Thailand \\
\hline 2010 fiscal balance & -1.5 & -4.6 & -3.9 & 2.4 & -2.7 \\
\hline 2009 fiscal balance & -1.6 & -5.5 & -3.9 & -0.9 & -3.2 \\
\hline Change in fiscal balance in 2010 & 0.1 & 1.0 & 0.0 & 3.3 & 0.4 \\
\hline Fiscal impulse (deterioration (-)/improvement(+)) & 0.1 & 0.8 & 0.1 & 2.2 & -0.3 \\
\hline Automatic stabilisers & 0.0 & 0.2 & 0.4 & 1.2 & 0.8 \\
\hline Additional interest spending & 0.1 & -0.1 & -0.4 & 0.0 & -0.1 \\
\hline \multicolumn{6}{|l|}{ Memorandum items: } \\
\hline Real GDP growth (in percent) & 6.0 & 6.7 & 7.0 & 15.0 & 7.5 \\
\hline Gross public debt to GDP ratio & 26.7 & 55.1 & 46.3 & 100.4 & 45.5 \\
\hline
\end{tabular}

Sources: IMF, World Economic Outlook, October 2010 and Fund staff estimates.

$1 /$ Net public sector debt is negative, as public sector assets are much larger than the gross public sector debt. Estimated gross official reserves in 2010 are US $\$ 194$ billion, in addition to at least US $\$ 100$ billion assets of the GIC Fund.

2/ For Indonesia and the Philippines, figures are for the central government.

Headline fiscal balances are expected to improve in most ASEAN-5 economies over the medium-term, but will remain above the pre-crisis levels (Table 1). Withdrawing policy stimulus is estimated to result in structural improvements in Malaysia and Singapore, in 2010, with small continued fiscal stimulus in Thailand. In Indonesia and the Philippines the fiscal stance is estimated to be broadly neutral (Table 3$){ }^{5}$ With strong economic recovery under way in most countries, automatic stabilizers are projected to further improve headline fiscal balances in 2010 .

\footnotetext{
${ }^{5}$ Despite the modestly expansionary budget deficit target (2.1 percent of GDP), under-spending will lead to a tighter budgetary stance in Indonesia, whereas in the Philippines planned stimulus withdrawal is delayed because of increased electoral spending.
} 
The post-crisis debt outlook in the ASEAN-5 is stronger than in advanced G-20 economies, but debt tolerance is usually considered to be lower than in advanced economies. ${ }^{6}$ At just under 40 percent of GDP on average, government debt is slightly higher than the emerging market average, while structural primary deficits are projected to remain considerable in some countries (Table 4). In Singapore, the public debt outlook is particularly strong despite the impact of the crisis, because the size of its foreign exchange assets accumulated in its two sovereign wealth funds is still far greater than its public sector debt stock. The public debt outlook is also resilient in Indonesia, where the debt-to-GDP ratio fell to 29 percent in 2009 (less than a third of its 2000 level). In the Philippines, the public debt ratio has also declined substantially. Nevertheless, there are still some risks reflecting narrow and volatile tax bases, rigid budget structures, and the low quality of public assets. Furthermore, fiscal space needs to be created to help address development challenges such as meeting infrastructure needs and alleviating poverty or to allow for counter-cyclical responses to future shocks. State-owned companies also pose additional fiscal burden in some countries. For instance, in the Philippines, non-financial public sector debt remains at a high level of 61 percent of GDP. Finally, even if fiscal and debt positions remain sound as in Singapore, managing age-related spending pressures will be important to contain debt increases in the future. The challenges of fiscal adjustment across advanced and emerging market economies have been extensively discussed in the May and November 2010 Fiscal Monitors.

Going forward, risks to the ASEAN-5 economies could also come from spillovers from advanced economies debt problems. Should high debt levels persist for many of the largest economies at the same time, higher real interest rates could ensue worldwide, with adverse consequences for private investment and global growth. Recent econometric evidence suggest that given the projected average increase in debt ratios in advanced economies, their

\footnotetext{
${ }^{6}$ Reinhart, Rogoff, and Savastano (2003) find that "safe" external debt levels for emerging market countries with default and inflation history are rather low (as low as 15 percent of GNP in some countries). Furthermore, high volatility of revenue stream often necessitates more conservative debt thresholds (Budina and van Wijnbergen, 2008).
} 
long-term real interest rates could increase by almost 2 percentage points over the medium -term, other things equal (IMF, 2010c). Such an increase in interest rates for advanced economies would adversely affect emerging economies financing conditions. Furthermore, high debt levels in many advanced economies could result in a more volatile external environment (e.g. volatile capital flows, commodity prices and exchange rates), which could have a negative economic impact on emerging market economies. There is also new evidence of an inverse relationship between initial debt and subsequent growth, controlling for other determinants of growth, based on a panel of advanced and emerging economies over almost four decades. ${ }^{7}$ The potential impact of these risks calls for further caution with respect to future deficits.

\section{Exit from Fiscal Policy Support}

Given the strong economic rebound in all the ASEAN-5, these economies are already beginning to identify and implement their exit strategies from fiscal policy support. It is important that the exit strategies aim at not only rolling back many of the fiscal stimulus measures, but also at establishing the foundations for strong, sustainable and balanced growth and at lowering public debt to create fiscal space for counter-cyclical fiscal policy responses to future shocks. It is desirable that fiscal exit strategies be transparent, comprehensive, and communicated clearly, with the goal of implementing them within a clearly-specified timeframe (IMF, 2009a).

With the economic recovery being more entrenched in the region, most ASEAN-5 economies have already started a gradual exit from fiscal policy support. Malaysia and Singapore have already started a gradual withdrawal of fiscal policy stimulus in 2010, while recent data suggests that fiscal withdrawal would likely be postponed till next year in the Philippines and Thailand. In Indonesia fiscal policy is likely to remain broadly neutral.

Beyond unwinding crisis-related fiscal stimulus measures, post-crisis exit strategies need to address medium-term fiscal challenges specific to the ASEAN-5. For example, some ASEAN-5 economies are facing risks reflecting narrow and volatile tax bases and rigid budget structures. Most of the ASEAN-5 will need to create fiscal space to address developmental challenges (meeting infrastructure needs and/or reducing poverty) while undertaking fiscal adjustment. When implementing their exit strategies, countries should thus avoid public investment cuts as a quick fix to achieve budget targets. Growth-enhancing structural reforms, which can stimulate private infrastructure investment, should also be a part of countries' fiscal exit strategies, as they could help sustain growth potential while easing the fiscal burden. Furthermore, enhancing fiscal institutions, medium-term budget frameworks and fiscal rules would be important in implementing fiscal goals. Finally,

\footnotetext{
${ }^{7}$ A 10 percentage point increase in the initial debt-to-GDP ratio is associated with a slowdown in annual real per capita GDP growth by 0.2 percentage point per year, with the impact being smaller in advanced economies (IMF, 2010c).
} 
revenue-based fiscal consolidation would be important in the ASEAN-5 economies, where governments are relatively small and the efficiency of tax collection is low. In view of these considerations, exit strategies would need to be supported by revenue enhancing measures and reorientation of spending priorities.

\section{The Role of Public Policy in Strengthening Future Growth Potential}

In addition to the near-term agenda of implementing the fiscal exit strategy, fiscal policy should also help strengthen the future growth potential in the ASEAN-5 economies. There is an important role for the governments of the ASEAN-5 economies in sustaining economic recovery through strengthening future growth potential. In particular, public policies could help meet vast infrastructure investment needs. There is also a need to support private consumption and to expand social safety nets to reduce poverty. The following two sub-sections discuss these challenges.

\section{A. Key Challenges: Addressing Infrastructure Gaps}

Higher infrastructure investment can have a positive impact on output and growth, if the quality of public investment is sufficiently high (IMF, 2004 and 2005, and Easterly, Irwin, and Serven, 2007). The impact of additional infrastructure is even greater for countries with initially lower levels of provision (Egert, Kozluk, and Sutherland, 2009). Success in this area depends on improvements in the quantity and quality of infrastructure services, and reductions in their cost. Governments can play an important role in this regard, through public investment. But given that structural primary deficits and public debt burdens in some of the ASEAN-5 countries are already high by emerging market standards, governments should also seek to stimulate private infrastructure investment. Public policy reforms that enhance competition and market based regulation can encourage private investment in infrastructure. Furthermore, greater use of Public Private Partnerships (PPPs), if well managed, could potentially allow the public sector to take advantage of private-sector efficiencies.

\section{Infrastructure Gap}

Infrastructure needs remain significant in most of the ASEAN-5 economies. While the region has some of the most modern infrastructure in the world, there are still large gaps in basic infrastructure. Sustained investment and efficiency in operations have helped some economies in the region - in particular, Singapore and Malaysia - to achieve considerable comparative advantage across infrastructure sectors (Annex). However, investment climate 
surveys indicate that inadequate infrastructure service provision is a serious obstacle to business development in Indonesia and the Philippines. ${ }^{8}$

Considerable potential exists for further improvements in the quality of transport, energy, and communications infrastructure. Acute gaps are perceived in virtually all key infrastructure sectors such as energy, transport (road, rails, water and air) and telecommunications in Indonesia and the Philippines (Table 5). For the Philippines, low quality and quantity of transport infrastructure (World Bank, 2009a) is an important contributor to the low ratings. Malaysia and Thailand, scored better for the quality of energy and technological infrastructure, but have needs in the area of transport infrastructure (roads and ports). ${ }^{9}$
Table 5. Ranking on Basic Infrastructure in the Asia-Pacific 1/

\begin{tabular}{lrr}
\hline Ranks & 1999 & 2009 \\
\hline Singapore & 8 & 2 \\
Hong Kong SAR & 19 & 5 \\
Australia & 1 & 12 \\
Japan & 20 & 15 \\
China & 13 & 16 \\
New Zealand & 15 & 21 \\
Malaysia & 26 & 22 \\
Korea & 41 & 23 \\
Taiwan Province of China & 23 & 27 \\
Thailand & 33 & 29 \\
India & 38 & 37 \\
Indonesia & 39 & 48 \\
Philippines & 47 & 57 \\
\hline
\end{tabular}

Source: IMD, World Competitiveness Yearbook, 2009.

$1 /$ Total number of countries in the world covered in the survey: 47 in 1999/2000, 57 in 2009.

\section{Private Infrastructure Investment}

The low rankings of infrastructure do not necessarily reflect the quantity of private infrastructure investment. Measured in absolute dollar terms, private investment in infrastructure in the low and middle income countries in East Asia appear to be relatively low compared to other regions (Figure 1) and in 2008, investment commitments - in the areas of energy, telecommunication, transport, and water and sewagedeclined to the lowest level

Figure 1. Investment Commitments to Infrastructure Projects with Private Participation in Developing Countires, by Region, 1990-2008 (In billions of US dollars)

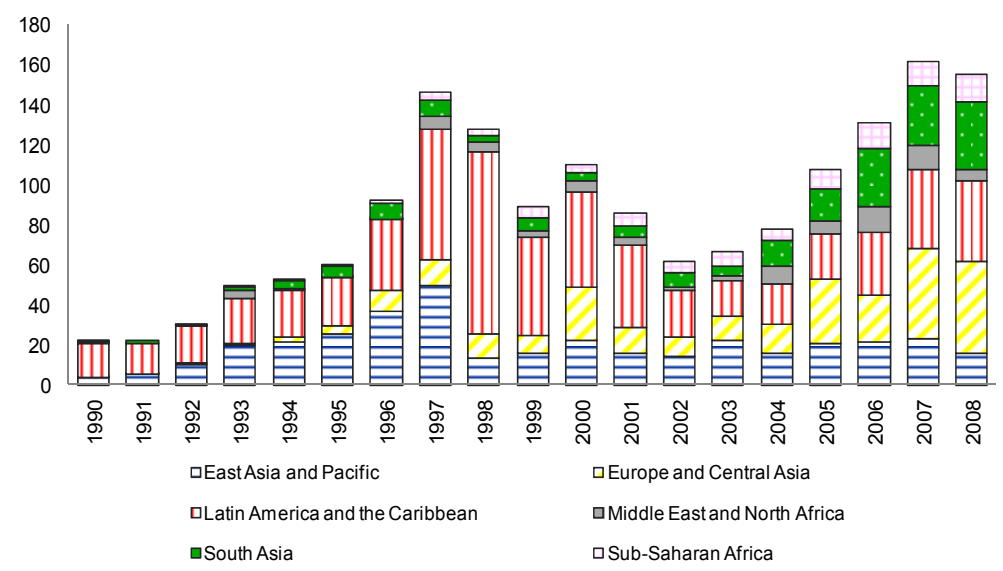

Source: The World Bank since 2002, well below their peak in 1997. However, measured as a share of GDP, private investment in infrastructure in the ASEAN-5 over 2001-08, is not particularly low as compared to other emerging economies

\footnotetext{
${ }^{8}$ Nearly 20 percent of respondents in investment climate surveys report that inadequate infrastructure service provision is a serious obstacle to the operation and growth of their business (ADB, JBIC, and World Bank, 2005, Connecting East Asia: A New Framework for Infrastructure).

${ }^{9}$ See World Economic Forum, 2009, The Global Competitiveness Report, 2009-2010.
} 
(World Bank PPI database). These trends and the low rankings suggest that efficiency of investment and project appraisal and selection process could be important challenges in the region.

\section{Public Investment}

Public investment levels have Figure 2. Gross Fixed Public Capital Formation generally declined and remain low in a number of ASEAN-5 economies. Malaysia's public investment rate has been relatively high, but has followed a downward trend over the past decade (Figure 2). Infrastructure investment was also quite low in some countries. For example, infrastructure investment in Indonesia stood at below 4 percent of GDP in 2007 (see (In percent of GDP)

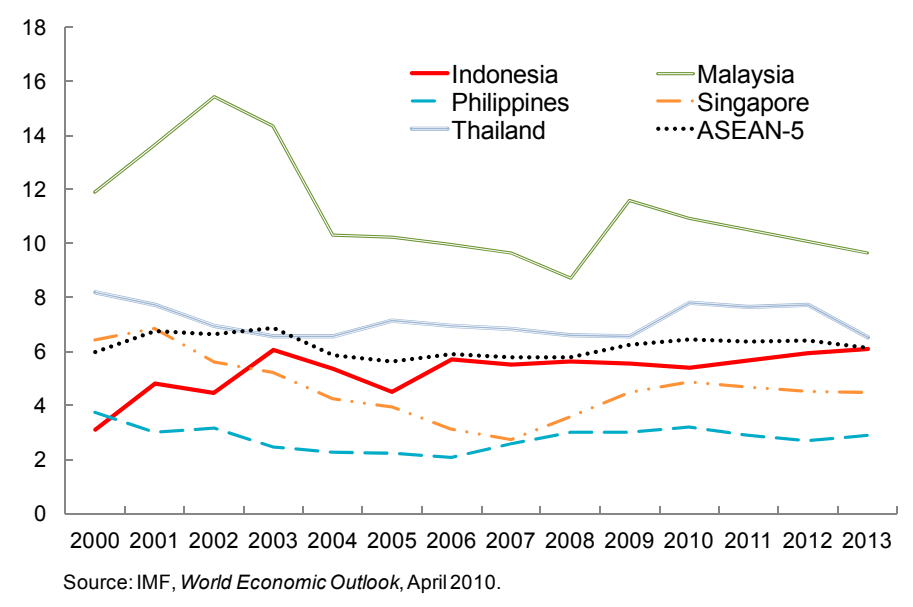
the discussion below). In Indonesia and the Philippines, public spending on infrastructure averaged about 3 percent of GDP over the past ten years.

\section{Policy Recommendations to Increase Investment}

To meet infrastructure needs, scaling up of public investment and improvements in the quality of spending are both needed in some of the ASEAN-5 countries. Public investment programs can be stepped up, where there is fiscal space to do so. Often this requires budget reforms aiming to improve administrative capacity to spend efficiently and to facilitate the implementation of capital projects. Using cost-benefit analysis is critical to ensure good quality of investment choices. For example, a high reliance on unsolicited proposals and the absence of a proper framework for evaluating public investment proposals has been a challenge in the Philippines (World Bank, 2009). Possible options to increase the influence of cost benefit analysis include making it public; imposing full disclosure and justification of undertaken investments; having the analysis performed by independent evaluators and linking it to fiscal planning, so that it feeds into long-term fiscal projections. ${ }^{10}$

Governments can also increase the use of public-private partnerships (PPPs) to increase investment in infrastructure, while ensuring a proper regulatory environment. Although there is a long history of PPP projects in some countries in the region, such as the Philippines, there is a lack of a strong institutional and procedural framework for planning and budgeting;

${ }^{10}$ See Easterly, Irwin and Serven (2007). 
moreover, clear principles for government involvement are absent. As a result, risks have not been optimally allocated between the public and private sector (World Bank, 2009a). To ensure adequate risk-sharing, decision making about the use of concessions and PPPs should be transparent. Proper monitoring and performance evaluation throughout the contract period are also important to guarantee value for money (Schwartz and others, 2008).

Public policies to promote private investment need to focus on strengthening the regulatory environment and enhancing market-based competition (Égert, Kozluk, and Sutherland, 2009). For example, policies that increase competition in infrastructure, allow for tariff-increases toward cost recovery and impose hard budget constraints on public utilities can help boost private investment in infrastructure sectors. Furthermore, removing barriers to entry can foster higher rates of investment in the network industries, especially in the energy and telecommunication sectors.

\section{B. Key Challenges: Strengthening Private Consumption, Alleviating Poverty and Preparing for an Ageing Population}

Strengthening social safety nets can play an important role in supporting private consumption and reducing poverty, ensuring durable and balanced growth. ${ }^{11}$ Lowering precautionary savings by strengthening social safety nets in countries where private consumption has lagged behind can also help growth rebalancing. The relative importance of these policy objectives vary within the ASEAN-5. While poverty reduction is a more significant challenge in Indonesia and the Philippines, the goal of sustaining higher private consumption growth is more relevant for Singapore and Malaysia.

Consumption patterns vary considerably across the ASEAN-5, reflecting differences in demographics, levels of financial development and social security

Table 6. Private Consumption (In percent of GDP)

\begin{tabular}{lcccc}
\hline & 1990 & 2000 & 2004 & 2008 \\
\hline Indonesia & 49.1 & 61.7 & 66.8 & 60.9 \\
Malaysia & 52.6 & 43.8 & 44.0 & 45.2 \\
Philippines & 71.4 & 69.6 & 68.7 & 71.1 \\
Singapore & 46.3 & 42.2 & 42.4 & 41.0 \\
Thailand & 55.9 & 56.1 & 57.2 & 54.8 \\
China & 50.6 & 46.2 & 39.9 & 37.3 \\
India & 66.5 & 63.5 & 59.6 & 54.0 \\
Korea & 51.6 & 54.8 & 52.6 & 54.5 \\
Vietnam & 89.6 & 66.5 & 65.1 & 67.3 \\
\hline
\end{tabular}

Source: IMF, World Economic Outlook. systems. Aside from income growth, these factors and their interactions play an important role in the behavior of savings and private consumption and the variations among these countries. For example, private consumption is relatively low and has declined in Malaysia and Singapore, whereas it is higher and has been on the rise in Indonesia and the Philippines (Table 6).

\footnotetext{
${ }^{11}$ For a discussion of the role of equity in sustainable growth, see Berg, Ostry, and Zettelmeyer (2008) and Tanzi, Chu, and Gupta (1999).
} 
- Demographics: An important determinant of household savings is the age profile of the population. In countries with increasing old-age dependency ratios, high savings rates may reflect the accumulation phase prior to the dissavings that will occur in the future. However, savings rate could remain high in old age, if the elderly enjoy additional income support through remittances or live in households with other earning family members. In contrast, declining savings rate in the Philippines is attributed to the high proportion of young dependents and the related spending needs for health and education (Bersales and Mapa, 2006).

- Level of financial development: The low level of financial development, including consumer credit, is one of the main causes for the high savings rate in much of Asia (Jha and others, 2009). Low access to credit strengthens the precautionary motive for savings. Limited access to finance, given a relatively underdeveloped corporate bond market, and low opportunity cost of funds from low real interest rates, have led firms to resort to internal finance, increasing the level of corporate savings as well. ${ }^{12}$

- $\quad$ Social security systems: Uncertainty in future spending such as old-age pensions and health care spending, due to a lack of a social security system is an important factor affecting household saving behavior. Improving the coverage of social security typically provides for higher and more consistent levels of consumption. In the Philippines, the increase in private consumption is attributed to the increased coverage ratio of the social security system (Terada, 2009, Chou and others, 2003).

Poverty alleviation is also an important goal for the ASEAN-5. Social spending needs are high given a large share of the population living below poverty levels, especially in Indonesia and the Philippines (Table 7). Earnings inequality is also relatively high among the ASEAN-5 compared to the region and the OECD, and has been rising (OECD, 2009).

Public social expenditure is relatively low in these economies and access to social services by the most vulnerable remains a challenge. In general, public spending on social safety nets and health is lower in most of Asia compared to the rest of the world (Table 8). Public health spending in the ASEAN-5, Table 7. Poverty and Inequality Indicators

\begin{tabular}{lccc}
\hline & $\begin{array}{c}\text { Population } \\
\text { Living Below } \\
\text { \$2 a Day } \\
\text { 1990-2005 }\end{array}$ & $\begin{array}{c}\text { Income } \\
\text { Share of } \\
\text { Highest } \\
\text { Decile } \\
2004-05\end{array}$ & $\begin{array}{c}\text { Income } \\
\text { Share of } \\
\text { Lowest } \\
\text { Decile }\end{array}$ \\
\hline Indonesia & 52.4 & 32.3 & 3.0 \\
Malaysia & 9.3 & $\ldots$ & $\ldots$ \\
Philippines & 43.0 & 34.2 & 2.2 \\
Singapore & $\ldots$ & 32.8 & 1.9 \\
Thailand & 25.2 & 33.4 & 2.7 \\
China & 34.9 & 34.9 & 1.6 \\
India & 80.4 & 31.1 & 3.6 \\
Asia-12 & 54.6 & 30.4 & 2.8 \\
OECD & $\ldots$ & 24.2 & 3.1 \\
\hline
\end{tabular}

Source: OECD (2009). estimated at 1 1 $\frac{1}{2}$ percent of GDP in 2005-06, lagged behind many Asian economies which

\footnotetext{
${ }^{12}$ High growth coupled with a low level of financial development and some policy induced measures that resulted in sizable retained profits in public enterprises, such as large subsidies on energy and land or monopoly rents combined with low dividend payouts are other factors affecting corporate savings in Asia (Jha and others, 2009).
} 
averaged 2 percent of GDP (OECD, 2009). Similarly, social expenditure, which includes spending on labor market programs, social insurance, social assistance, micro-area based programs and child protection averaged 2.7 percent of GDP in Indonesia, Malaysia and the Philippines in 2004-05, compared to 5.1 percent of GDP in Asia and 30 percent of GDP in the OECD (OECD, 2009). Increasing public spending on health and education could foster a welcome increase in private consumption by reducing the need to self-insure to finance future expenditures. This will also result in higher human capital investment, thus increasing long term growth potential. A simulation using household data in China suggests that a sustained 1 percent of GDP increase in public expenditures, distributed equally across education, health, and pensions, would increase permanently the household consumption ratio by 11/4 percentage points of GDP (Baldacci and others, 2010).

Looking ahead, some ASEAN-5 countries will be facing significant fiscal pressures from the need to expand coverage and from adverse demographic trends. In emerging ASEAN and other Asian economies, spending on pensions and health care is relatively modest today, reflecting the relatively young population structure (Figure 3). For example, in the Philippines, Indonesia and Thailand, spending on pensions and health is less than 2.5 percent of GDP. However, by 2050, this spending is projected to nearly double, given increasing old age dependency ratios (IMF, 2010d and 2010e). Furthermore, the need to expand coverage to wider sections of the population is likely to result in even larger increases in spending over the next few decades. In these countries, preserving fiscal space would require that the expansion of pension and health coverage be done in a fiscally sustainable manner. Finally, in countries where demographic pressures are more severe, such as Malaysia and Singapore, age-related spending is expected to rise much more rapidly: for example, in Malaysia, pension and health spending is expected to increase by 4.5 percent of GDP over 2010-50. 
Figure 3. Dependency Ratios $1 /$
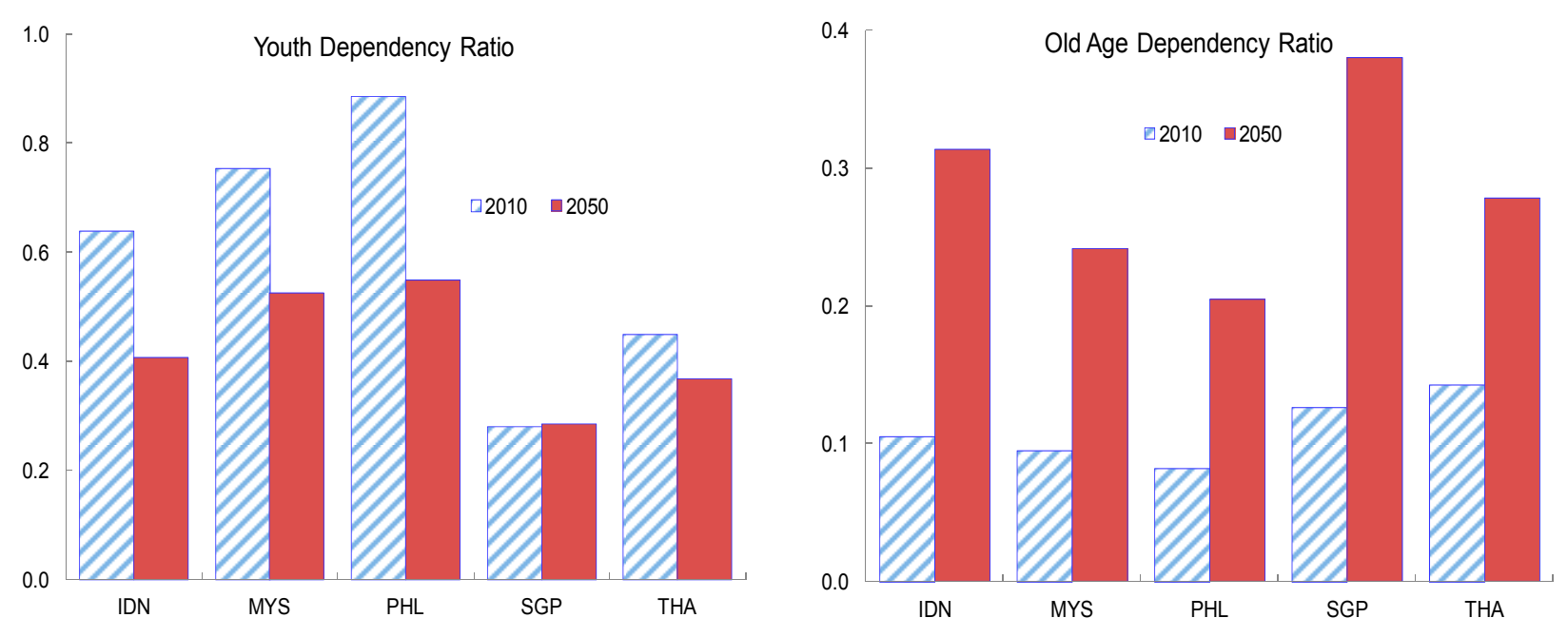

Sources: Census Bureau and the United Nations.

$1 /$ Youth dependency ratio is defined as the population aged 19 years and under, to the population age 20-65 years. Old-age dependency ratio is defined as the population aged over 65 years to the population aged $20-65$ years.

\section{Fiscal Space to Foster Medium-Term GroWth}

A balancing act lies ahead for fiscal policy in creating fiscal space while meeting new demands on the budget as discussed in the previous section. ${ }^{13}$ Fiscal space will need to be created to help meet large infrastructure needs in transport, energy, and communications, and to increase social spending. At the same time, successful exit from policy support would require some fiscal tightening in most countries, aiming at gradual reduction in public debt to create room for countercyclical fiscal policy against future shocks (see Section I). This is especially important in the context of policy challenges presented by renewed capital flows to the region. Finally, unfavorable demographic trends can present new fiscal challenges in some countries.

This section outlines ways to create fiscal space that are of relevance to the ASEAN-5 economies. Some studies have argued that expenditure-based consolidations are more growth-friendly and have longer-lasting impact, based on experience in (largely European) advanced economies (Alesina and Perotti, 1996, and Alesina and Ardagna, 2009). However, for emerging economies, where the size of the government is relatively small and effective tax ratios are low, revenue based consolidation can have a more favorable impact on growth if the savings are spent on more productive expenditures. The focus for creating fiscal space for the ASEAN-5 is thus on revenue mobilization and optimization of the composition of budgetary expenditure by reprioritizing public expenditure, improving the efficiency of

\footnotetext{
${ }^{13}$ See Heller (2005) and IMF (2004) and (2005) for a discussion on fiscal space.
} 
spending, as well as reforms which could help limit future fiscal pressures. Finally, improvements in fiscal institutions would be needed to achieve these objectives.

\section{A. Creating Fiscal Space by Re-Orienting Spending Priorities ${ }^{14}$}

Expenditure rationalization focused on improving the efficiency of spending is generally preferred for creating fiscal space. Experience from expenditure adjustment episodes has highlighted the importance of improving the composition of spending. For example, reforms focused on reducing the wage bill, as well as subsidies and transfers, while protecting or increasing capital expenditure have been associated with more durable reforms and have helped ensure higher growth and enhanced fiscal space, especially in emerging markets (Gupta et al, 2003). By reducing unproductive expenditures, such measures strengthen the credibility of the government's commitment to reform. Furthermore, successful consolidations based on current expenditures are accompanied by structural reforms. For example, elimination of generalized subsidies by reforming public enterprises has played an important role in successful consolidations (Mackenzie, Orsmond, and Gerson, 1997, and Kumar, Leigh, and Plekhanov, 2007).

While there are sizable differences in the size and composition of government spending across the ASEAN-5 countries, there remains scope for improving spending composition. Primary spending is generally lower in ASEAN-5 countries (except in Malaysia) than in other Asian, emerging and advanced economies. This mainly reflects relatively small social benefits (Tables 9). Capital expenditures are also generally lower, compared to other Asian and emerging economies, especially as a share of primary spending. Nevertheless, there is wide variation across countries. The wage bill, as a share of GDP, is generally not very high, but constitutes a high share of primary spending in some countries such as the Philippines. In order to improve the composition of spending, it would be important to ensure that other primary spending such as social and capital spending grow faster compared to the wage bill.

There is also scope to enhance efficiency of spending through better targeting. An area where there exists substantial scope for improvement in some ASEAN-5 countries is fuel subsidies. Tax inclusive fuel subsidies, measured as the difference between the benchmark price and the domestic retail price, have been generally higher in emerging and developing economies compared to the advanced economies. ${ }^{15}$ Among the ASEAN-5, these subsidies, in particular, are quite large in Indonesia and Malaysia. In Indonesia, for example, fuel subsidies comprised about $1 / 3$ of total central government spending over the last decade. Fuel subsidies are also inefficient, inequitable, and environmentally unfriendly. For example, empirical

\footnotetext{
${ }^{14}$ For a more detailed discussion on spending and revenue measures, see IMF (2010e).

${ }^{15}$ See Coady and others (2010), Annex 5 in IMF (2010c). The benchmark price is calculated as the U.S. international U.S. dollar price at the nearest international hub adjusted for standard shipping, distribution and retailing costs.
} 
studies found that benefits from these subsidies generally accrue to higher income households (Augustina and others, 2009). Similarly, Indonesia, Malaysia and the Philippines all have universal food price subsidies rather than social transfers targeting the poor. Furthermore, coverage of the poor population by social spending is limited. For example, in the Philippines, food subsidies which account for over 70 percent of transfers in 2007, had 40 percent leakage rate to the non-poor (World Bank, 2009b).

Table 9. General Government Expenditure Structure: Selected Asian Economies, 2008

\begin{tabular}{|c|c|c|c|c|c|c|c|}
\hline & $\begin{array}{c}\text { Primary } \\
\text { Expenditure }\end{array}$ & $\begin{array}{l}\text { Compensation } \\
\text { of Employees }\end{array}$ & $\begin{array}{c}\text { Social } \\
\text { Benefits 1/ }\end{array}$ & $\begin{array}{c}\text { Capital } \\
\text { Spending }\end{array}$ & $\begin{array}{l}\text { Compensation } \\
\text { of Employees }\end{array}$ & $\begin{array}{c}\text { Social } \\
\text { Benefits 1/ }\end{array}$ & $\begin{array}{c}\text { Capital } \\
\text { Spending }\end{array}$ \\
\hline & \multicolumn{4}{|c|}{ (In percent of GDP) } & \multicolumn{3}{|c|}{ (In percent of primary expenditure) } \\
\hline Indonesia 2/ 3/ & 18.6 & 4.6 & 0.8 & 5.7 & 24.9 & 4.3 & 30.6 \\
\hline Malaysia $2 /$ & 27.5 & & 6.5 & 3.0 & $\ldots$ & 23.6 & 10.9 \\
\hline Philippines 2/3/ & 13.1 & 5.0 & 3.1 & 2.4 & 38.1 & 23.6 & 18.3 \\
\hline Singapore $2 /$ & 17.8 & $\ldots$ & $\ldots$ & 1.7 & $\ldots$ & $\ldots$ & 9.6 \\
\hline Thailand 2/ & 20.4 & 7.6 & 3.3 & 2.6 & 37.3 & 16.2 & 12.7 \\
\hline China 2/ & 20.5 & $\ldots$ & 6.0 & $\ldots$ & $\ldots$ & 29.2 & $\ldots$ \\
\hline India $2 /$ & 23.6 & $\begin{array}{l}\cdots \\
\cdots\end{array}$ & 4.1 & $\ldots$ & $\begin{array}{l}\cdots \\
\cdots\end{array}$ & 17.4 & $\cdots$ \\
\hline Vietnam 2/ & 28.6 & $\ldots$ & 4.9 & 8.9 & $\ldots$ & 17.1 & 31.1 \\
\hline Korea 4/ 5/ & 29.1 & 7.3 & 5.9 & 6.0 & 25.1 & 20.1 & 20.7 \\
\hline Average (unweighted) & 22.1 & 6.1 & 4.3 & 4.3 & 31.3 & 19.0 & 19.1 \\
\hline
\end{tabular}

Sources: IMF, World Economic Outlook and Global Finance Statistics; Eurostat; ILO; and Fund staff estimates.

1/ Social benefits data (except for Korea) is from ILO Social Security Department Global Extension of Social Security (GESS) database, accessible at http://www.socialsecurityextension.org/gimi/gess/ShowTheme.do?tid=1985. For Indonesia, includes public pensions only.

2/ WEO.

3/ Central government.

4/ 2006 data.

5/ OECD; capital spending proxied by "gross fixed capital formation."

Policy measures should thus focus on gradually reducing the subsidies, particularly for energy products, while developing compensating mechanisms and more effective targeting criteria to protect the vulnerable. If properly targeted, such spending not only is more effective in providing social protection but is also less likely to be saved and can thus generate a higher multiplier effect. Designing transfer programs that can be targeted to the poorest segment of society who are most likely to be liquidity constrained would also help shore up domestic demand without tradeoffs with income distribution.

While age-related spending pressures are limited today, it would be important to ensure that public pension and health obligations do not rise dramatically over time, especially as income levels rise and coverage expands. Some countries such as Singapore, Indonesia, and Malaysia have a defined contribution system for pension benefits which limits fiscal risks. For others with defined benefit systems, the design of the pension system will need to limit the generosity of benefit levels, encourage pre-funding, and improve compliance to increase the contribution base. Containing health care costs, which can be more challenging, will 
require that appropriate incentives are put in place to limit excess cost growth, such as by reforming provider payment systems.

Controlling fiscal risks, including from guarantees and other contingent liabilities, is also needed to reduce fiscal vulnerability and to preserve fiscal space. While PPPs usually transfer some of the risks to the private partner, the state often retains important (often hidden) fiscal risks from contingent liabilities. In addition to risks from guarantees and other contingent liabilities related to SOEs and PPPs, a few countries are also exposed to large risks from oil price/natural resource price volatility. These risks tend to increase fiscal vulnerability and can therefore crowd out fiscal space for productive public spending. Some progress toward moving to greater overall fiscal transparency and disclosure of fiscal risks has been achieved, for example, where the budget documents now include a fiscal risk statement (e.g., in Indonesia).

\section{B. Creating Fiscal Space through Revenue Reforms}

Revenue based fiscal consolidation is important for creating fiscal space in countries with low or declining revenue to GDP ratios. ${ }^{16}$ For the ASEAN-5, revenue reform is crucial for creating fiscal space given the pressures for higher spending as discussed above. Furthermore, in contrast to many advanced and emerging countries, which implemented expenditure-based fiscal stimulus packages, some of the ASEAN countries, such as Indonesia and the Philippines, implemented stimulus packages comprised mostly of permanent tax cuts. In these cases, policy exits will require revenue improvements to avoid further cuts in already low public expenditure.

Raising revenues in an increasingly globalized economy will require strengthening broad-based taxes on relatively immobile bases and improving tax compliance. Given the distortionary effects of corporate income tax, reforms need to focus on broadening consumption and property taxes that are less harmful to growth. The declining trends in statutory CIT rates reflect greater international tax competition and the likely permanent reduction in the CIT revenue effort due to reduced contributions from the financial sector makes this strategy all the more important.

Broadening tax bases by reducing exemptions and incentives and revenue administration reforms will be needed to create fiscal space. In some countries, such as Indonesia and the Philippines, tax efficiency ratios, notably for the VAT, measured as the tax revenue divided by the tax rate, are low compared to the average for East Asia and for middle income countries and could be improved. The reliance on goods and services taxes is also relatively low in Malaysia and the Philippines (Tables 10 and 11). The efficiency of corporate income tax is very low in Indonesia, in particular. Thailand, on the other hand, has relatively high

\footnotetext{
${ }^{16}$ Gupta and others (2003), Ardagna (2004); IMF (2006).
} 
efficiency in consumption taxes, but low efficiency in personal income tax. In Indonesia, revenue reforms will also need to seek increased reliance on non-mineral revenue sources.

Table 10. Revenue Structure: Selected Asian Economies, 2008 (Or most recent available)

\begin{tabular}{|c|c|c|c|c|c|c|c|c|}
\hline & Year & $\begin{array}{c}\text { Tax } \\
\text { Revenue }\end{array}$ & $\begin{array}{c}\text { Other } \\
\text { Revenue }\end{array}$ & $\begin{array}{c}\text { Taxes } \\
\text { on Income } \\
\text { Profits, and } \\
\text { Capital Gains }\end{array}$ & $\begin{array}{c}\text { Taxes on } \\
\text { International } \\
\text { Trade }\end{array}$ & $\begin{array}{c}\text { Taxes } \\
\text { on Income } \\
\text { Profits, and } \\
\text { Capital Gains }\end{array}$ & $\begin{array}{c}\text { Taxes on } \\
\text { Goods and } \\
\text { Services }\end{array}$ & $\begin{array}{c}\text { Taxes on } \\
\text { International } \\
\text { Trade }\end{array}$ \\
\hline & & \multicolumn{4}{|c|}{ (In percent of GDP) } & \multicolumn{3}{|c|}{ (In percent of tax revenue) } \\
\hline Indonesia & 2008 & 13.3 & 7.1 & 6.6 & 0.7 & 49.7 & 39.8 & 5.5 \\
\hline Malaysia & 2003 & 16.6 & 5.8 & 10.6 & 1.2 & 63.9 & 28.9 & 7.2 \\
\hline Philippines & 2007 & 14.0 & 1.7 & 6.4 & 3.2 & 45.7 & 25.7 & 22.9 \\
\hline Thailand & 2007 & 17.4 & 3.7 & 7.3 & 1.1 & 42.0 & 50.0 & 6.3 \\
\hline China & 2006 & 9.4 & 0.9 & 2.7 & 0.5 & 28.7 & 64.9 & 5.3 \\
\hline India & 2007 & 11.6 & 2.0 & 5.5 & 2.1 & 47.4 & 34.5 & 18.1 \\
\hline Vietnam & 2004 & 21.5 & 3.3 & 8.2 & 3.0 & 38.1 & 45.1 & 14.0 \\
\hline Average & & 14.8 & 3.5 & 6.8 & 1.7 & 45.1 & 41.3 & 11.3 \\
\hline
\end{tabular}

Sources: IMF, Government Finance Statistics, International Financial Statistics, and World Economic Outlook.

Combating tax abuse could also yield considerable revenue, which requires significant capacity building in revenue administration. Revenue agencies can play an important role in encouraging formalization by helping new entrepreneurs, and taking visible enforcement action against the shadow economy to establish tax discipline. Strengthening revenue administration would involve developing risk-based compliance strategies; strengthening legal frameworks, including the powers of revenue agencies (e.g., in accessing information and conducting audits); and exploiting new information technology to better manage taxpayers' compliance information.

\section{Frameworks for Maintaining Fiscal Credibility}

Well designed and efficiently managed fiscal institutions can play a central role in the post-crisis fiscal strategies. There is scope in a number of countries to improve the breadth, depth and timeliness of fiscal reporting, and more fully explore the risks surrounding their fiscal forecasts. In addition, clearly articulated fiscal objectives, comprehensive and binding medium-term budget frameworks, greater independent scrutiny, along with a stronger focus on performance would enhance fiscal management further. Introduction of fiscal rules, possibly supported by Medium-Term Budgetary Frameworks (MTBFs) and independent fiscal institutions can help promote fiscal discipline, provided sufficient political commitment to reform exists (IMF, 2009b). Rules that take into account cyclical developments can help ensure countercyclical policies, though adjusting for cyclical effects presents challenges in emerging economies.

Institutional improvements can help manage region specific challenges. As debt levels are still relatively high in some countries, frameworks/rules should aim explicitly at reducing 
public debt ratios. Debt targets should have a broad institutional coverage encompassing various contingent liabilities and risks. Guarantees provided to financial and other sectors should be publicly disclosed and incorporated in fiscal targets. When feasible, this could include estimating the expected guarantee cost and the maximum probable loss (Value-at-Risk). A range of possible qualitative and quantitative approaches can be applied, depending on the nature of the risk, data availability and significance of risk exposures. ${ }^{17}$ In addition, a wider use of MTBFs is needed to make fiscal developments consistent with long-term objectives (e.g., financing infrastructure). Enhancing automatic spending stabilizers to support private consumption during downturns is also critical. In countries highly dependent on natural resources (e.g., oil), fiscal frameworks/rules should focus on managing volatile resource revenue and exposure to commodity price volatility. ${ }^{18}$

Table 11. Tax Efficiency Indicators (In percent)

\begin{tabular}{|c|c|c|c|c|c|c|c|c|}
\hline & Philippines 1/ & Indonesia 2/ & Thailand $3 /$ & Malaysia 2/ & Singapore & $\begin{array}{c}\text { East Asia and } \\
\text { Pacific }\end{array}$ & $\begin{array}{c}\text { Low- } \\
\text { Mid-Income }\end{array}$ & World \\
\hline & 2007 & 2008 & 2007 & 2008 & 2007 & \multicolumn{3}{|c|}{2008 or latest available } \\
\hline Total tax revenues to GDP & 14 & 13 & 17 & 17 & 14 & 20 & 21 & 20 \\
\hline \multicolumn{9}{|l|}{ VAT } \\
\hline Rate & 12 & 10 & 7 & $\ldots$ & 7 & 11 & 16 & 16 \\
\hline Revenue share of GDP & 2 & 4 & 4 & 2 & $\ldots$ & 5 & 7 & 6 \\
\hline Tax efficiency 4/ & 18 & 42 & 54 & $\ldots$ & $\ldots$ & 48 & 47 & 40 \\
\hline \multicolumn{9}{|l|}{ Corporate income tax } \\
\hline Rate (maximum) & 30 & 30 & 30 & 27 & 18 & 28 & 26 & 26 \\
\hline Revenue share of GDP & 4 & 1 & 5 & 8 & $\ldots$ & 6 & 3 & 3 \\
\hline Tax efficiency & 12 & 3 & 17 & 30 & $\ldots$ & 20 & 13 & 13 \\
\hline \multicolumn{9}{|l|}{ Personal income tax } \\
\hline Rate (maximum) & 32 & 30 & 37 & 28 & 20 & 29 & 27 & 30 \\
\hline Revenue share of GDP & 2 & 4 & 2 & 3 & $\ldots$ & 4 & 3 & 4 \\
\hline Tax efficiency & 7 & 14 & 6 & 9 & $\ldots$ & 14 & 10 & 12 \\
\hline
\end{tabular}

Sources: IMF, Government Finance Statistics and World Economic Outlook; and The World Bank (2010).

1/ Budgetary central government.

2/ Consolidated central government.

3/ General government.

4/ Tax efficiency is defined as tax revenue divided by tax rate.

\section{Conclusions}

With the recovery of economic activity being more entrenched, the ASEAN-5 economies are now beginning to formulate and implement their medium-term fiscal consolidation strategies. These efforts, together with relatively strong pre-crisis fiscal positions, are expected to

\footnotetext{
${ }^{17}$ See Brixi and Schick (2002) and Cebotari and others (2008).

${ }^{18}$ For a more detailed discussion on the role of fiscal policy in managing oil revenue volatility, see Budina and van Wijnbergen (2008) and Davis, Ossowski and Fedelino (2008).
} 
contain headline fiscal deficits and to maintain debt burdens well below those in advanced G-20 economies.

Looking ahead, fiscal policies face two key challenges. First, in some economies, debt ratios are still relatively high by emerging market standards. Even emerging economies with relatively low debt levels still remain vulnerable to shocks given narrow and volatile tax bases and risks of spillovers from advanced economies. There is thus a need to restore fiscal space for countercyclical responses to shocks. Second, long-term growth potential is constrained, to varying degrees across the ASEAN-5, by infrastructure gaps, declining private consumption and ageing populations.

What public policies could help address these long-term growth challenges?

- $\quad$ Promoting private infrastructure investment and enhancing public investment Key reform priorities are: (i) market-based regulation and competition to provide adequate incentives for private investment in infrastructure and for PPPs; (ii) an adequate policy framework for PPPs, with disclosure of related fiscal risks; and (iii) increasing the quality and quantity of publicly-provided infrastructure services.

- $\quad$ Supporting private consumption, alleviating poverty and preparing for an ageing population: Key reform priorities are: (i) expanding social spending on health, pensions and education to reduce the need for precautionary savings, thereby reversing the trend of declining private consumption in some of the ASEAN-5;

(ii) strengthening of social safety nets to help alleviate poverty; and (iii) containing future fiscal pressures arising from population ageing by improving the design of the pension and health care system.

What policies could create the necessary fiscal space for additional public spending in these areas?

- $\quad$ Broadening tax bases can increase tax revenue efficiency.

- $\quad$ Containing wage bills, transfers, and subsidies, including by improved targeting and rationalizing of subsidies.

- $\quad$ Increasing the efficiency of public investment to ensure better quality and lower costs through improvements in project appraisal and selection.

- $\quad$ Taking advantage of private-sector efficiencies through PPPs, provided adequate safeguards and frameworks are in place.

- $\quad$ Controlling fiscal risks, including from guarantees and other contingent liabilities to reduce fiscal vulnerability and to preserve fiscal space in the future. 
- $\quad$ Reforming pensions and health entitlements to ensure that coverage is increased in a fiscally sustainable manner.

- $\quad$ Medium-term fiscal strategies should be transparent, comprehensive, and clearly communicated early on, with the goal of lowering public debt within a clearly-specified timeframe. Stronger fiscal institutions such as medium-term budget frameworks can help to underpin these fiscal efforts. 


\section{Annex. Quality of Basic and Technology Infrastructure 1/}
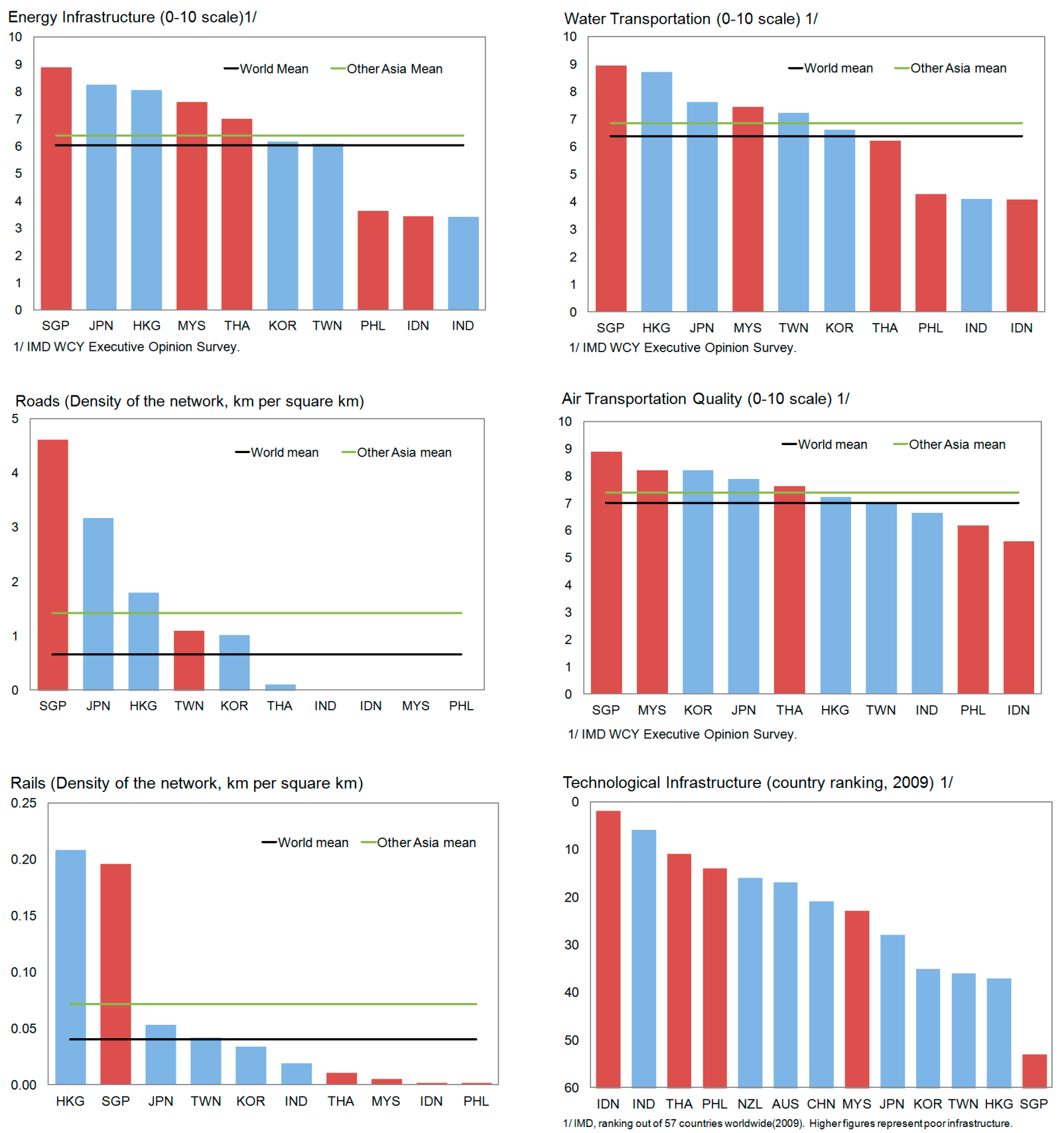

Source: IMD, World Competitiveness Online, 1995-2010.

1/ For energy, air and water transport, the charts plot results from an executive opinion survey based on an index from 0 to 10 (infrastructure is adequate and efficient).Countries are also ranked by the quality of technological infrastructure (a composite ranking encompassing computers, internet, fixed and mobile telephone use) in 20091 being the best and 57 the worst; and for Rails and Roads figures show quantity indicators. 


\section{References}

Asian Development Bank, Japan Bank for International Cooperation, and the World Bank, 2005, Connecting East Asia: A New Framework for Infrastructure.

Alesina, Alberto, and Roberto Perotti, 1996, "Fiscal Adjustments in OECD Countries: Composition and Macroeconomic Effects," NBER Working Paper No. 5730 (Cambridge, Massachusetts: National Bureau of Economic Research).

Alesina, Alberto, and Silvia Ardagna, 2009, "Large Changes in Fiscal Policy: Taxes versus Spending,” NBER Working Paper 15438, (Cambridge, Massachusetts: National Bureau of Economic Research).

Ardagna, Silvia, 2004, "Fiscal Stabilizations: When Do They Work and Why?" European Economic Review, Vol. 48, No. 5, pp. 1047-1074.

Augustina, C. and others, 2009, "Black Hole or Black Gold? The Impact of Oil and Gas Prices on Indonesia's Public Finances”, World Bank Policy Research Working Paper No. 4718 (Washington: World Bank).

Berg, Andrew, Jonathan Ostry, and Jeromin Zettelmeyer, 2008, "What Makes Growth Sustained?” IMF Working Paper 08/59 (Washington: International Monetary Fund).

Bersales, Lisa G. and Dennis Mapa, 2006, "Patterns and Determinants of Household Saving in the Philippines," prepared under the EMERGE Project of USAID. Available via the Internet: www.stat.upd.edu.ph/ARTICLES/Article3/Paper BERSALES MAPA.pdf.

Brixi and Schick (2002), Government at Risk: Contingent Liabilities and Fiscal Risk, The World Bank and Oxford University Press, 2002,

Budina, Nina and Sweder van Wijnbergen, 2008, "Managing Oil Revenue Volatility in Nigeria: The Role of Fiscal Policy," in Africa at a Turning Point? Growth, Aid and External Shocks, Chapter 10 (Washington: World Bank).

Cebotari, A. and others, 2008, Fiscal Risks - Sources, Disclosure, and Management, Washington, available at http://www.imf.org/external/pp/longres.aspx?id=4265

Coady, David, Robert Gillingham, Rolando Ossowski, John M. Piotrowski, Shamsuddin Tareq, and Justin Tyson, 2010, "Petroleum Product Subsidies: Costly, Inequitable, and On the Rise," IMF Staff Position Note No. 2010/05 (Washington: International Monetary Fund). 
Cottarelli, Carlo and José Viñals, 2009, "A Strategy for Renormalizing Fiscal and Monetary Policies in Advanced Economies," IMF Staff Position Note No. 2009/22 (Washington: International Monetary Fund).

Davis, Jeffrey M., Roland Ossowski, and Annalisa Fedelino, 2003, Fiscal Policy Formulation and Implementation in Oil-Producing Countries (Washington: International Monetary Fund).

Easterly, William, Timothy Irwin, and Luis Servén, 2007, "Walking Up the Down Escalator: Public Investment and Fiscal Stability," World Bank Policy Research Working Paper No. 4158 (Washington: World Bank).

Égert, Balázs, Tomasz Kozluk, and Douglas Sutherland, 2009, "Infrastructure and Growth: Empirical Evidence," OECD Economics Department Working Papers No. 685, (Paris: Organization for Economic Co-operation and Development).

Gupta, Sanjeev, Emanuele Baldacci, Benedict J. Clements, and Erwin Tiongson, 2005, "What Sustains Fiscal Consolidations in Emerging Market Countries?” IMF Working Paper 03/224 (Washington: International Monetary Fund).

— , and Carlos Mulas-Granados, 2004, "Expenditure Composition, Fiscal Adjustment and Growth in Low-Income Countries," IMF Working Paper 02/77 (Washington: International Monetary Fund).

Heller, Peter S., 2005, “Understanding Fiscal Space,” IMF Policy Discussion Paper No. 05/4 (Washington: International Monetary Fund).

Horton, Mark A., Manmohan S. Kumar, and Paolo Mauro, 2009, "The State of Public Finances: A Cross-Country Fiscal Monitor," IMF Staff Position Note 09/21 (Washington: International Monetary Fund).

International Monetary Fund, 2004, "Public Investment and Fiscal Policy" Available via the Internet: http://www.imf.org/external/np/fad/2004/pifp/eng/

— 2005, "Public Investment and Fiscal Policy—Lessons from the Pilot Country Studies" Available via the Internet: http://www.imf.org/external/np/pp/eng/2005/040105a.htm

— 2009a, "Global Economic Prospects and Principles for Policy Exit, prepared for Meetings of G-20 Finance Ministers and Central Bank Governors, November 6-7, 2009.

— , 2009b, "Fiscal Rules: Anchoring Expectations for Sustainable Public Finances," Available via the Internet: http://www.imf.org/external/np/pp/eng/2009/121609.pdf. 
, 2010a, "Exiting from Crisis Intervention Policies" Available via the Internet: http://www.imf.org/external/np/pp/eng/2010/020410.pdf

- 2010b, "Fiscal Policy Issues after the Crisis," paper presented at the Conference on the Global Financial and Economic Crisis, ADBI-MoF PRI-Hitotsubashi University, Center for Intergenerational Studies-International Development Research Centre, Tokyo, January.

— 2010c, "IMF Fiscal Monitor: Fiscal Challenges Beyond the Crisis," May 2010, (Washington: International Monetary Fund).

— 2010d, "Aging and Fiscal Sustainability in APEC Economies," paper prepared for the $17^{\text {th }}$ APEC Finance Ministers' Meeting (FMM), February, Washington, DC.

- 2010e, "From Stimulus to Consolidation-Revenue and Expenditure Policies in Advanced and Emerging Economies," Available via the Internet: http://www.imf.org/external/pp/longres.aspx?id=4452.

Irwin, Timothy C., 2007, Government Guarantees: Allocating and Valuing Risk in Privately Financed Infrastructure Projects (Washington: World Bank).

Jha, Shikha, Eswar Prasad, and Akiko Terada-Hagiwara, 2009, "Saving in Asia: Issues for Rebalancing Growth,” ADB Economics Working Paper Series No. 162 (Manila: Asian Development Bank).

Kumar, Manmohan S., Daniel Liegh, and Alexander Plekhanov, 2007, "Fiscal Adjustments: Determinants and Macroeconomic Consequences," IMF Working Paper 07/178 (Washington: International Monetary Fund).

Mackenzie, George A., David W. H. Orsmond, and Philip R. Gerson, 1997, The Composition of Fiscal Adjustment and Growth: Lessons from Fiscal Reforms in Eight Economies, IMF Occasional Paper No. 149 (Washington: International Monetary Fund).

Organization for Economic Co-operation and Development, 2009, Society at a Glance, Asia-Pacific Edition (Paris).

Schwartz, Gerd, Ana Corbacho, and Katja Funke, 2008, Public Investment and Public-Private Partnerships. Addressing Infrastructure Challenges and Managing Fiscal Risks (Washington: International Monetary Fund).

Tanzi, Vito, Ke-young Chu, and Sanjeev Gupta, 1999, Economic Policy and Equity (Washington: International Monetary Fund).

World Bank, 2010, "Philippines Public Expenditure Review, Gearing Public Finance for Inclusive Growth," forthcoming (Washington: World Bank). 
World Bank, 2009a, "Philippines Transport for Growth, an Institutional Assessment of Transport Infrastructure," Report No. 47281-PH, (Washington: World Bank).

World Bank, 2009b, "Philippines Development Report, 2009, Battling the Global Recession," Washington D.C.

World Economic Forum, 2009, Global Competitiveness Report 2009-2010. 